\title{
REFLECTIONS AND COMMENTS: 'TRUMPISM POLITICS: IS IT TRULY APPEALING?'
}

\section{CHARLES MICALLEF}

\begin{abstract}
:
It is envisaged that Donald Trump won the US Presidential election due to his distinct political strategy, termed as 'Trumpism' or 'Trump factor'. Through comparative and critical thinking, two considerations have been suggested that can possibly answer why Trumpism politics could be appealing. First, Trump was not hesitant to state his views even if these sounded radical: no sweet words, no inhibitions. Furthermore, Trump is sending a message that there is a limit to where one can arrive with diplomacy and partnership agreements for global security issues that are of immense importance to society like: uncontrolled immigration, ISIS terror and North Korean threats. This article can serve as a platform for thorough academic research on Trumpism. A survey on the US-Trump population followed by a number of focus group meetings can tell whether Trump was elected by default or because people desired his radical ideologies.
\end{abstract}

\section{Keywords:}

diplomacy; immigration; partnership; radical; security; transparency; Trump factor; Trumpism politics

\section{Authors:}

CHARLES MICALLEF, Ministry of Health, Malta, Email: carmel.micallef@gov.mt

\section{Citation:}

CHARLES MICALLEF (2017). Reflections and Comments: 'Trumpism politics: is it truly appealing?'. International Journal of Social Sciences, Vol. VI(1), pp. 90-96., 10.20472/SS.2017.6.1.007

\section{Disclaimer:}

- The author's views have no association with the entities he is affiliated with.

- The author also acknowledges that as news on Donald Trump is continuously emerging, the phenomenon of Trumpism as presented in this short article is only based on what was publicly known until the time he was elected to power.

- As Trumpism is still in its infancy it is understood why a literature search yielded practically nothing relevant to the way the subject is tackled in this paper. Hence, some of the references are not of high standard. This however, has little impact on the way the essay has been presented.

Disclosure:

This paper overrides an incomplete article titled, 'Trumpism versus seemingly honest (traditional) politics: why is Trump a winner?' which was accepted for journal publication soon after it was sent for preliminary (pre-submission) assessment. It was not peer-reviewed and several parts, including 
the author details and references, were incorrectly edited. Furthermore, the paper was placed in the public domain without the author's consent by a predatory publisher. The author is ready to disclose the evidence of this case with anyone wishing to know more.

Conflicts of interest:

The author has no competing interests to declare. 


\section{Introduction}

Several millions of people around the world cannot accept Donald Trump's historic victory as the $45^{\text {th }}$ President of the USA on November $9^{\text {th }}, 2016$. Sectors of humanity which felt offended by some of Trump's comments have every right to be concerned. However, the scope of the reflections in this short article is not to go into the moral values of Trump but to assess his distinct political strategy, now widely known as 'Trumpism' or 'Trump factor'. There were pundits who were so flustered by Trump that they had trouble accepting Trumpism politics (Tarnoff, 2016). It could be that several politicians fear that by time Trump would prove them wrong in their talk-talk political approaches.

\section{The research questions}

Trump is different from most of the politicians we know. Although the Republican and President-elect was out-polled by Democrat Hillary Clinton with almost 2.9 million votes (Krieg, 2016), three research questions of significance to this article tend to be overshadowed as the governance controversy lingers on. What makes Trump so distinct as to attract nearly sixty-three million votes (46.1\%)? Why is Trumpism appealing? Is it appealing, after all? By applying some comparative and critical thinking, two broad hypotheses or considerations can be identified that could shed answers to these three related questions.

\section{Trump's distinct strategy: two hypotheses}

1. First consideration. Trump was not hesitant to state his extreme views and to propose drastic measures. Two of the main ingredients that characterise this side of Trumpism are, xenophobia and misogyny (Tarnoff, 2016). Other politicians would support every issue - even contrasting ones such as excessive hunting and nature conservation - thus looking nice with practically every sector of society. Therefore, whether one agrees with Trump's extreme ideas or not, it remains indisputable that Trump has openly stated his beliefs without any fears. In other words, Trump's success could be based on "I am what you see": no masks, no sweet words and no inhibitions.

2. Further consideration. Trump could be sending a message to the world that there is a limit to where one can arrive with diplomacy and partnership agreements. It seems that lip service alone is not working on global security issues that are extremely popular and of public concern on the social media like uncontrolled immigration, ISIS ${ }^{1}$ terror and North Korean threats. Although for many critics Trump has no visionary foreign policy, Trump showed that he has got the guts to do it! For example, can illegal immigration be halted? In his candidacy announcement speeches, Trump proposed the idea of building a wall along America's southern border (CBS News, 2016). As for Islamic terrorism,

\footnotetext{
${ }^{1}$ ISIS stands for Islamic State of Iraq and Syria.
} 
Trump wants to pursue aggressive joint military operations to crush and destroy ISIS (The Campaign, 2016). Furthermore, in an interview with the New York Times he suggested that he would support Japan and South Korea in developing their own nuclear arsenals (Cahill, 2016).

\section{Past and present}

Since time immemorial, mankind wanted warriors to rule and protect them. For example, despite that Jesus Christ was never afraid to take a stand in public and there were many instances when the Saviour scorned the wealthy in support of the marginalized, the Jewish people are, until this day, expecting their 'Messiah' as a political ruler and a King, who would reign over Israel forever (EveryStudent.com, n.d.). Moreover, the New Testament is not accepted as part of their Bible.

\section{Reliability}

Some critics also share the same thoughts regarding Trumps' strategy that led to his success and these reflections should serve as further basis to analyse Trumpism. Let us consider two quotes from the comments of Moore (2016) and apply them to the two considerations that have already been highlighted on Trump's success:

Quote 1. "She (Clinton) represents the old way of politics, not really believing in anything other than what can get you elected. That's why she fights against gays getting married one moment, and the next she's officiating a gay marriage." This tallies with the first consideration on Trump's victory.

Quote 2. "We have to vote for Trump. We HAVE to shake things up." This corresponds with the second consideration.

\section{Literature review}

Usually, the literature search and review comes ahead of any research question but due to the way the subject of Trumpism is analysed in this article, the scanty pre-election literature about Trumpism is best dealt retrospectively, just prior to making the recommendations.

A Google Scholar search covering political science in English language using two key words, 'Donald Trump' and 'Trumpism', as the main inclusion criteria yielded very little to the way the subject has been tackled in this paper. Nevertheless, the three relevant scholarly contributions that were identified shed some light on what is being conveyed in this paper even though they appeared in the public domain before Trump's electoral victory. Although it could be that some of these authors did not envisage that Trumpism would eventually reign, when some highlights of their contributions are analysed, the 
hypotheses of this reflective study and the recommendations that follow become further strengthened.

Following a study carried out between September 17, 2015 and December 22, 2015, Wang, Li and Luo (2016) analysed four dimensions of follower demographics of Trump and Clinton: social status, gender, race and age. Of particular interest to this analysis was social influence. It was found that the Trumpists were more polarized than the Clintonists. The latter were also found to be more racially diverse. This all makes sense to the observations made in this article because in Trumpism there seems to be no middle ground and extremism is likely to triumph over moderation.

According to Giroux (2016), the emergence of a new form of authoritarianism has been witnessed; one that constitutes a kind of anti-politics. However, a strong central power may be needed if Trump is to implement the drastic actions he has highlighted in his candidacy strategy otherwise the traditional talk, talk politics might have been the alternative path. In another commentary Trump has stampeded the Republican Party and he has done this using a class-based divide-and-rule strategy (Trubowitz, 2016).

\section{Recommendations: urge to analyse Trumpism}

It is undisputable that Trump has sent a global message that he is different from most of the politicians and political leaders we know. It is for this reason that the phenomenon of Trumpism has to be studied by experts in the field of politics. If Trump only got one third of the electorate, Trumpism would still be significant and has to be analysed. Even if Trump's Presidency fails to implement the promised Trumpism, the 'Trump factor' has established itself as an independent survival in the political arena. As Parameswaran (2016) pointed out, there is reason not to discount the fact that the message may survive at least in some form even without its messenger. Therefore, this analysis can serve as a platform for thorough academic research on Trumpism.

Opinionists, instead of delving into the real causes which led to over sixty-two million Americans who voted in favour of Trump, are making comparisons with Brexit - Britain's historic referendum of June 23, 2016 to exit from the European Union. Time will tell whether Brexit meets Trumpism (D'Ancona, 2016) or whether Brexit and Trumpism are different 'beasts' (Montgomerie, 2016). What matters for the scope of this short article is that experts in politics should analyse without delay the needs of the people as reflected in their votes for Trump, which needs are probably also similar to those of British citizens and other nations.

\section{Proposed research methodology}

A survey on a naturalistic, purposeful sample of the US-Trump population followed by a number of focus group meetings can tell whether Trump was elected by default or because people truly want to see his radical ideologies being implemented. Therefore, 
as an interpretative theory can be built from the emerging data, a new, theoretical sample is selected to examine the phenomenon of Trumpism into further depth.

Of particular concern in a retrospective study of this type is memory bias which may impair the recall of memory. It is for this reason why in the previous section emphasis was laid on the words 'without delay'. Moreover, Trump's Presidency and his executive orders may alter the judgements of the study participants as it is not easy to separate Trump from Trumpism.

\section{Conclusion}

Whether Trump remains consistent and trustworthy is yet to be seen; what is known for sure is that soon after he was elected as President, he started moderating his talk. However, to acknowledge Trump's unique elements that led to his victory does not necessarily mean that one is supporting his ideologies. Time will tell whether Trump's radical ideas that contributed to his electoral win (apart from his celebrity status and his populism or unique way of communicating with the American people which were both instrumental in his journey to the White House) will be fair and that they would work in practice.

We should also remember that whereas practically all political leaders around the world were, until the eve of the election pro-Clinton, soon after, they congratulated Trump. So, let us officially recognise Trumpism and see why people in America and perhaps internationally want this revolutionary politics of drastic change and action to reign. Are people simply tired with the traditional politics of sweet talk and talk or they genuinely want Trumpism to stay forever?

\section{References}

Cahill P (2016) Where does Donald Trump stand on Syria, ISIS, North Korea? NBC News Available at: http://www.nbcnews.com/news/world/where-does-donald-trump-stand-syria-isis-north-korean688031 (accessed 20 January 2017).

CBS News (2016) 30 of Donald Trump's wildest quotes. Available at: http://www.cbsnews.com/pictures/wild-donald-trump-quotes/14/ (accessed 20 January 2017).

D'Ancona M (2016) Brexit meets Trumpism: the malign new force spanning the Atlantic. The Guardian Available at: https://www.theguardian.com/commentisfree/2016/nov/13/rexit-trumpism-donaldtrump-nigel-farage (accessed 20 January 2017).

EveryStudent.com (n.d.) Judaism and Christianity. Available at: http://www.everystudent.com/wires/judaism.html (accessed 20 January 2017).

Giroux H (2016) Political frauds, Donald Trump and the ghost of totalitarianism. Knowledge Cultures, 4 (5), pp. 95-108. 
Krieg G (2016) It's official: Clinton swamps Trump in popular vote. CNN Politics Available at: http://edition.cnn.com/2016/12/21/politics/donald-trump-hillary-clinton-popular-vote-final-count/ (accessed 20 January 2017).

Montgomerie T (2016) Brexit and Trumpism are very different beasts. The Times Available at: http://www.thetimes.co.uk/article/brexit-and-trumpism-are-very-different-beasts-7b8rmbdgs (accessed 20 January 2017).

Moore M (2016) 5 reasons why Trump will win. Available at: http://michaelmoore.com/trumpwillwin/ (accessed 20 January 2017).

Parameswaran P (2016) Can Trumpism Survive Without Trump? The Diplomat Available at: http://thediplomat.com/2016/10/can-trumpism-survive-without-trump/ (accessed 20 January 2017).

Tarnoff B (2016) The triumph of Trumpism: the new politics that is here to stay. The Guardian Available at: https://www.theguardian.com/us-news/2016/nov/09/us-election-political-movement-trumpism (accessed 20 January 2017).

The Campaign (2016) Foreign policy and defeating ISIS. Trump Pence - Make America great again Available at: https://www.donaldjtrump.com/policies/foreign-policy-and-defeating-isis (accessed 20 January 2017).

Trubowitz P (2016) How the 'Trump factor' came to dominate the 2016 election. USAPP - United States Politics and Policy Available at: http://blogs.Ise.ac.uk/usappblog/2016/01/29/how-the-trump-factorcame-to-dominate-the-2016-election/ (accessed 20 January 2017).

Wang Y, Li Y and Luo J (2016) Deciphering the 2016 U.S. Presidential Campaign in the Twitter Sphere: a comparison of the Trumpists and Clintonists. Available at: https://arxiv.org/abs/1603.03097 (accessed 20 January 2017). 